\title{
Integrating spatial models into regional energy system optimisation: focusing on biomass
}

Ingrid Schardinger

Studio iSPACE, Research Studios Austria Forschungsgesellschaft mbH, Salzburg, Austria

Florian Botzenhart

Max-Planck-Institute for Plasmaphysics, Garching bei München, Germany

Markus Biberacher

Studio iSPACE, Research Studios Austria Forschungsgesellschaft mbH, Salzburg, Austria

Thomas Hamacher

Institute for Energy Economy and Application Technology, Technische Universitaet Muenchen, Munich, Germany, and

Thomas Blaschke

Centre for Geoinformatics, University of Salzburg, Salzburg, Austria and

Studio iSPACE, Research Studios Austria Forschungsgesellschaft mbH, Salzburg, Austria

\begin{abstract}
Purpose - The purpose of this paper is to outline an integrative modelling approach that includes agricultural and forestry process chains in an energy system model, on a regional scale. The main focus is on land use for biomass production, aimed at satisfying the demands for energy, food, and materials. Design/methodology/approach - The described model combines geographic modelling with a linear optimisation approach. The cost-based optimisation of the energy system includes agricultural and forestry process chains. The system's commodities and processes are identified and these are linked appropriately in the specifications of the reference system. Spatial models provided geographically specific input data for the optimisation; these spatial models were based on publicly available data, regional heat and electricity demands, and regional biomass potentials. The optimisation tool was applied in two case studies.

Findings - The optimisation results allow an improved understanding of the interdependencies between regional agricultural and forestry structures and the regional energy system. Future developments of the energy system can be quantified. The application of the model in the case studies has revealed the limits on biomass availability, even in rural areas, and the fossil fuel price sensitivity of an optimal system setup.

Originality/value - Geographic models linked to a forecast model approach and based on publicly available data allow a high spatial resolution by taking into account the region-specific conditions and mean that the modelling approach is transferrable to other regions. This paper provides an initial insight into the linkage between bottom-up optimisation and spatial modelling, representing an innovative approach that is yet to be well explored.

Keywords Austria, Agriculture, Forestry, Energy technology, Rural areas, Spatial data structures, Biomass, Land use, Regional scale

Paper type Research paper
\end{abstract}

Regional

energy system optimisation

Received 4 November 2010 Revised 15 January 2011, 31 May 2011 Accepted 7 August 2011

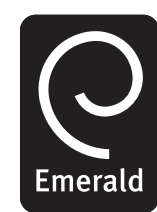

International Journal of Energy Sector Management Vol. 6 No. 1, 2012 


\section{IJESM}

6,1

\section{Introduction and objective}

International energy policy targets such as the EU's 20-20-20 Directive require application on both national scale and, in the long-term, on a regional level. The potential regional contribution to a sustainable energy system is highly dependent on regional characteristics that need to be taken into account when defining regional targets.

Future energy requirement projections indicate a strong need for biomass integration and an enhanced use of biomass is consequently to be expected (Berndes et al., 2003; Yamamoto et al., 2001; Alfonso et al., 2009). Demand-driven studies estimate a worldwide increase in bioenergy demand of up to several hundred exajoules per year (Berndes et al., 2003). Yamamoto et al. (2001) expect surplus arable land to become available for bioenergy crops in North America, Western Europe, Oceania, Latin America, Former USSR and Eastern Europe. Alfonso et al. (2009) state that agriculture should provide a greater biomass contribution to renewable energy and see the greatest potential resting with cogeneration applications. Increasing fossil fuel prices are likely to result in substantial improvements in the relative economic benefits of using bioenergy (Kalt et al., 2010). A wide range of biomass resources is available and its regional use contributes additional benefits to the local economy. Biomass has the advantage of being one of the few renewable energy sources that is storable. There is, however, no generally accepted way to define a maximum desirable level of biomass exploitation: restrictions on the amount of land area available and competitive land use between food and fuel production (Guggenberger and Blaschka, 2009; Buchgraber, 2007), as well as the costs involved in the biomass supply chain (Rentizelas et al., 2009), are seen as the main limiting factors. The complexity of energy systems means that integrative concepts are required that are able to take into account regional structures of energy demand and supply, costs, land use competition, $\mathrm{CO}_{2}$ emissions, and technological data.

The main objective of our approach is the development of a computer-based tool for optimising regional energy systems, in order to offer small rural regions a manageable decision support tool for the elaboration of energy concepts.

Within this main objective are the following sub-goals:

(1) definition and specification of a reference system;

(2) preparation of spatial regional data;

(3) development of an optimisation model;

(4) integration of spatial data into the optimisation model;

(5) scenario development; and

(6) application of the optimisation tool in two case studies.

Regional input data for the optimisation model are available from public databases. Geographic information systems (GIS) have been used in our approach as they enable a high spatial resolution for the decision support tool, allowing precise recommendations for action to be derived. Furthermore, the use of public databases in combination with GIS methods means that the model can be easily transferred to other regions. Since the focus of the model is on biomass, agricultural and forestry processes and commodities are included in the reference energy system (RES), as well as the direct energy-relevant components.

Renewable energy resources - especially biomass - and energy demand structures are closely linked to spatial conditions. Spatial approaches have therefore increasingly 
become the subject of research: spatial indicators for the evaluation of sustainable autarchic regions have been developed by comparing the potentials of biomass, photovoltaic, hydro, and wind power within regional demand structures (Mittlböck et al., 2006). Some studies have focused on a specific energy source in the context of energy demand (Dorfinger, 2007; Schardinger et al., 2008; Masera et al., 2006). A study by Prinz et al. (2009) was dedicated to the systematic spatial modelling of several renewable energy sources and their relationships to spatial planning. Other GIS-based studies have addressed the cost evaluation of delivered energy crop feedstocks (Graham et al., 2000, 1997). Dominguez and Amador (2007) discussed the application of GIS in the field of renewable energy and stressed the advantages of GIS-based support tools for rural electrification plans and renewable energy integration.

Numerous studies have been carried out into energy system optimisation (Biberacher, 2007b; Eherer and Baumann, 2004; Ordecsys et al., 2004; Botzenhart, 2007; Rentizelas et al., 2009; Kalt et al., 2010; Nagel, 2000). Biberacher (2007b) developed a snapshot model on a global scale, with high spatial and temporal resolution and a reduced technological database. Eherer and Baumann (2004) presented a global forecast model, which was implemented using the TIMES model generator and which was based on spatially aggregated data. The EFDA-TIMES model is a long-term global energy model disaggregated into 15 world regions (Ordecsys et al., 2004). Kalt et al. (2010) introduced the Green-XBA simulation-model, which contains a myopic optimisation and operates on a national level without any spatial differentiation within the country. Energy system optimisation models on a regional scale also exist (Rentizelas et al., 2009; Nagel, 2000; Botzenhart, 2007), but these approaches do not have a high spatial resolution or make use of publicly available regional data.

Connolly et al. (2010) have presented a review of computer tools for analysing the integration of renewable energy into various energy systems. These tools are diverse regarding the regions they analyse, the objectives they fulfil, and the technologies they consider, although most of the 37 reviewed tools perform a cost optimisation. The approach that we have used is based on the work of Botzenhart (2007), which focuses on TIMES as a cost optimisation model and investigates rural areas on a regional scale. The empirical base data of Botzenhart's model (Botzenhart, 2007) is, in our approach, replaced by freely available geographical data in order to enable an automated evaluation of a regional energy system, and the spatial dimension is developed in greater detail.

Our linking of the TIMES optimisation model with spatial approaches using GIS relates to previously described integration possibilities (Biberacher, 2007a, b; Mühlich et al., 2009). Biberacher (2007a) focused on integration on a global scale, while Mühlich et al. (2009) developed spatial models for urban energy systems on a regional scale, including estimation of heat demand with a high level of spatial disaggregation and optimisation of the distribution network. Alfonso et al. (2009) combined spatial and temporal approaches with a focus on biomass management optimisation, especially from a logistical point of view. Our aim has been to develop spatial and temporal approaches for the integration of food production into energy system modelling.

\section{Methodology}

The presented approach aims for a holistic representation of a rural energy system. Figure 1 shows an overview of the workflow. 


\section{IJESM}

6,1

8

\subsection{Definition of a rural reference system}

The specifications of the reference system identify the commodities and processes to be modelled and link them appropriately. The approach focuses on biomass as an energy resource for the production of heat and electricity, although other renewable energy sources such as ambient heat, photovoltaic, and solar heat are also included. Land use for the production of food and materials is integrated into the model in order to take into account the competition for agricultural land.

The processes and commodities identified for the modelled rural agricultural and forestry systems are shown in Figure 2. The agricultural area input into the reference system is divided into separate categories for grassland and cropland, with both of these land categories being further subdivided into several classes according to the yield potentials of the individual agricultural lots. The harvesting input is also divided into several processes with respect to specific crop rotations. Outputs from these processes are crops either for use either as animal fodder or for energy production. The harvesting processes for cropland also distinguish crop rotations with intensive management, which only applies to those areas with high yield potentials. The diverse crops from the harvesting processes of agricultural areas serve as input into dairy cattle husbandry, beef cattle husbandry, cattle breeding and pig husbandry. The outputs from these processes are therefore milk, beef, pork, young cattle and liquid manure. The manure can be transported to a fermenter and converted into biogas.

The forest harvesting process produces a number of different commodities, for which a fixed mean proportion of wood fuel, wood pulp, assorted special timber, and saw logs is assumed in our model. A more detailed differentiation of forest yield potentials is not modelled because of the lack of available data. The output commodities from the harvesting processes are converted through chipping and splitting processes into wood chips and split logs, or sold on the open market. Wood chips and split logs may serve as input to the regional energy system or may be sold on the open market.

The presented production chain results in three different types of output: commodities to meet the regional food demand, commodities sold on external markets, and commodities for the regional energy system. All processes of the agricultural and forestry systems have investment costs, operation and maintenance costs, efficiencies, conversion factors, and lifetimes that are specified in our model. The assumptions used for the model are derived from literature research and are listed in the Appendix.

The energy system and its identified processes and commodities are shown in Figure 3. Input commodities can be divided into three groups: external energy sources, biomass sources from the regional agricultural and forestry systems, and regionally

Figure 1. Workflow

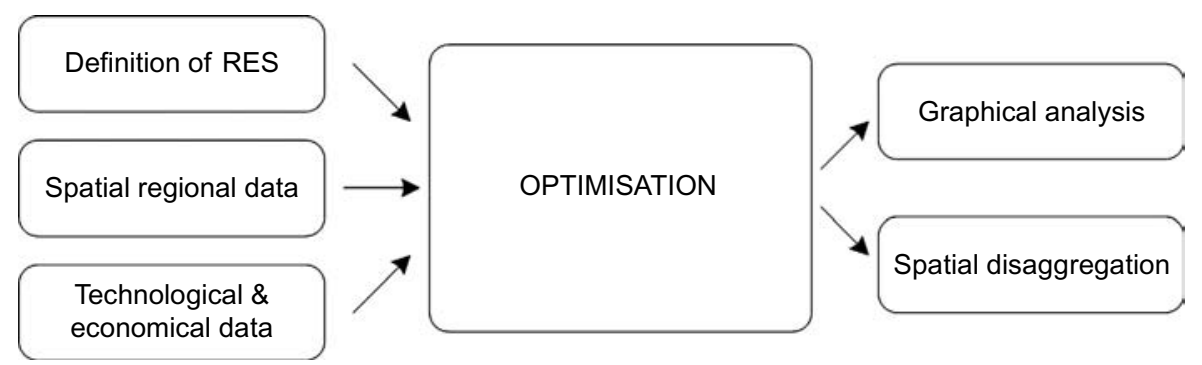



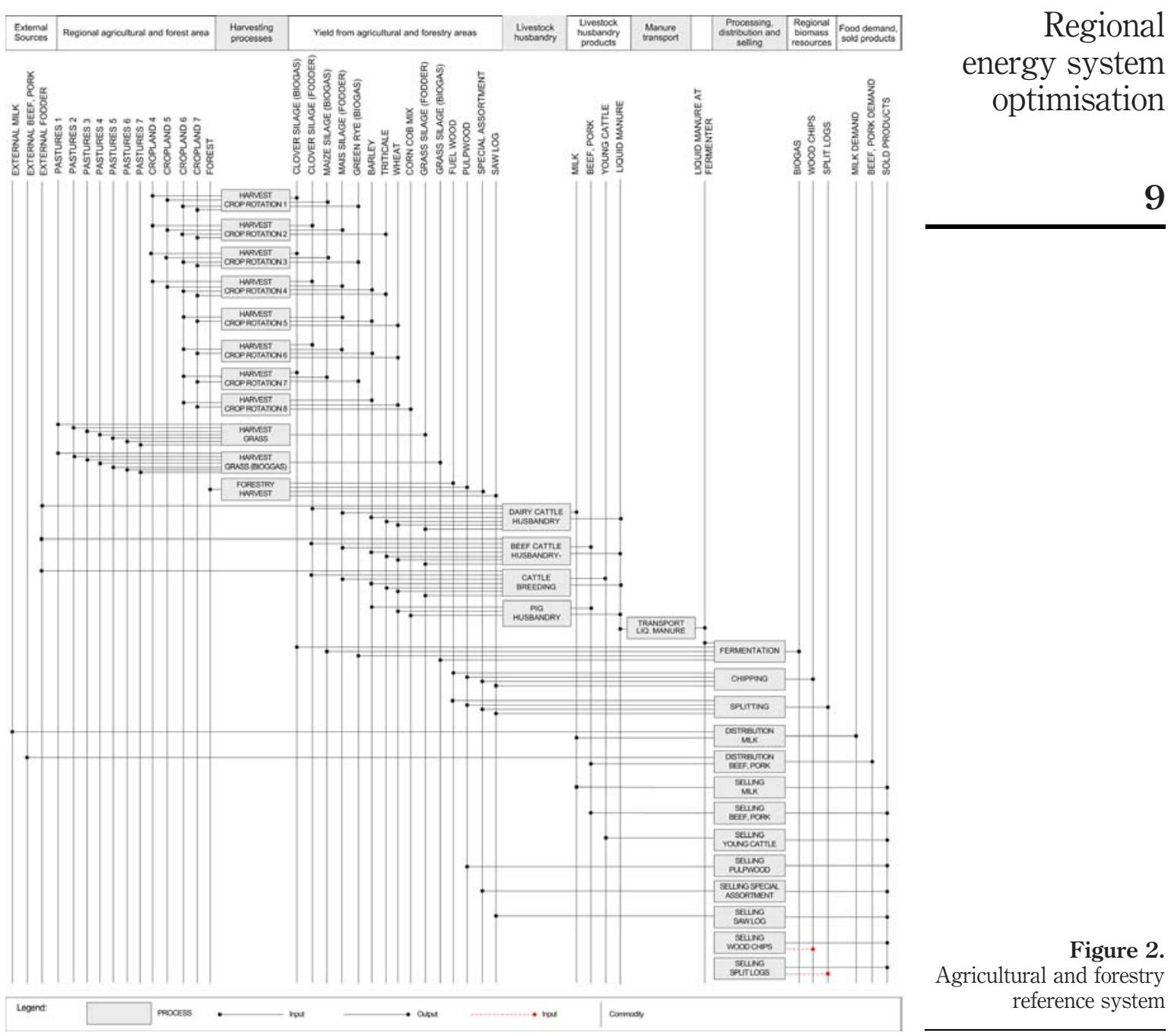

Figure 2.

Agricultural and forestry reference system

available areas for other renewable energy sources. The most common conversion technologies (according to available statistics) are modelled, and their outputs of electricity, district heat, and high and low temperature heat are used to meet the heat and electricity demand.

\subsection{Spatial models}

Publicly available data have been used in order to create an easily transferable model. The availability, completeness, spatial resolution, and data quality of various sources have been evaluated with respect to the use of their geographic data to estimate biomass potentials, including Corine Land Cover 2006, the Digital Land Register, Statistics Austria, and the INVEKOS database. The INVEKOS data are part of the Integrated 

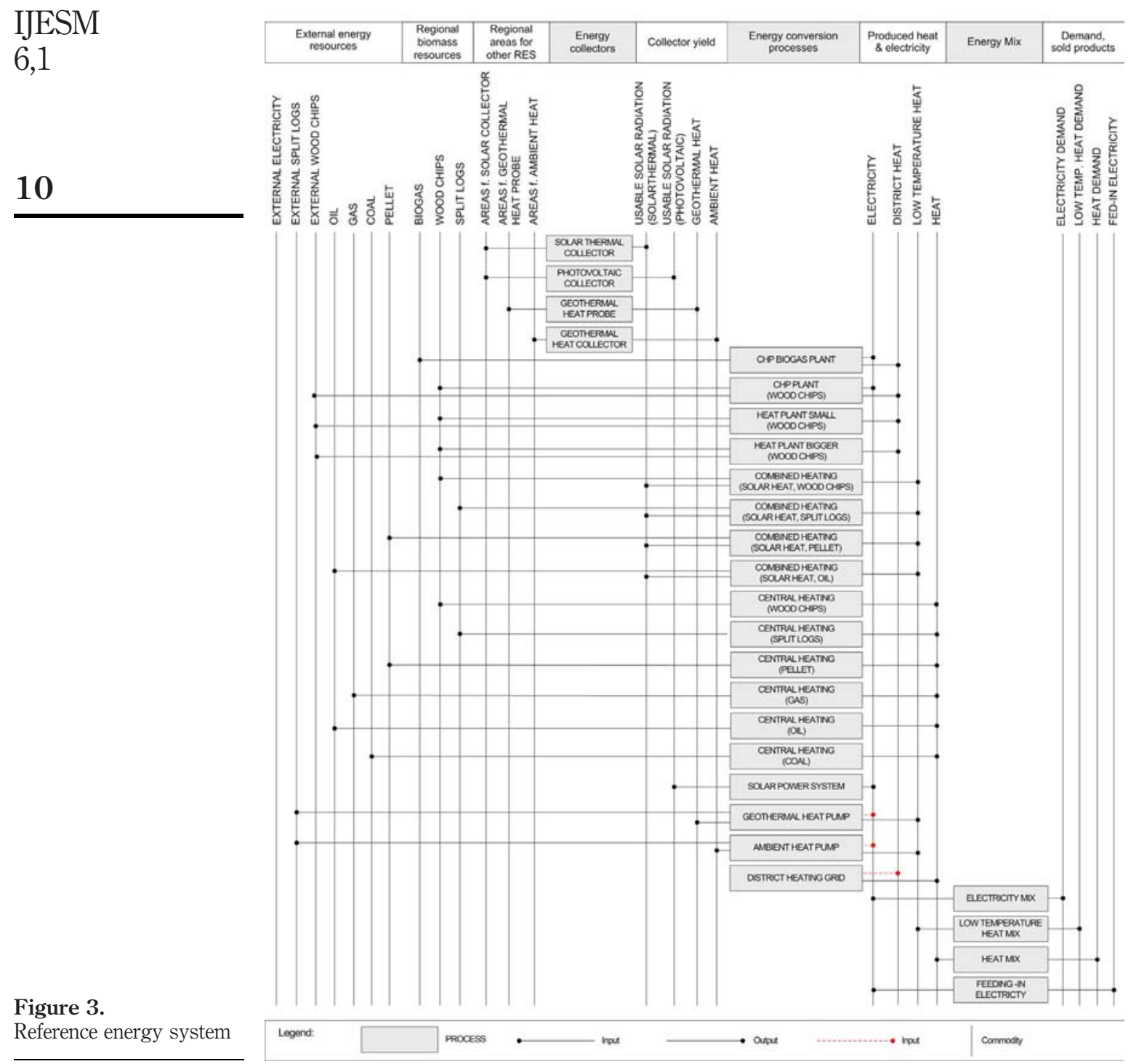

Figure 3.

Reference energy system

Administration and Control System established by the EU Member States in order to achieve a common agricultural policy: they are very accurate and up to date, but they are not publicly available due to privacy constraints and data politics. An aggregated version of these data will be available from Statistics Austria in the future, but was not available at the time of this project. Corine Land Cover data are derived from Landsat satellite images and available Europe-wide, but the spatial resolution is rather low for our regional approach and this data-set does not provide spatially differentiated information on biomass yield. The Digital Land Register proved to be the most suitable 
data source for the spatial modelling of biomass potentials on a regional scale. This data-set is publicly accessible for a small fee and contains a yield index. The yield index gives information on specific yield conditions for each individual agricultural lot, based on an expert evaluation of the land that forms part of the agricultural tax system in Austria and Germany. Relief and climate are included in the evaluation of biomass yield, as well as the soil type and condition. The index ranges from 1 to 100.

In order to model the energy yield of agricultural areas specific yields were assigned to geographically explicit areas. Robust values for agricultural yields were derived from published literature (Buchgraber et al., 2003; BMLFUW, 2008; Hrbek et al., 2007; Leonhartsberger, 2008; Botzenhart, 2007; Mittlböck et al., 2006; Paar and Nowak, 1991). A selection of potential crop rotations was initially identified by obtaining the currently most applied crop rotations in the first test region of St Roman. Since the yield potentials for the agricultural lots in this region were at the lower end of the range, the regional crop rotation system was specified for these particular yield conditions. Relevant crop rotation systems were then applied for areas with higher yield potentials. The applied crop rotations and their yields are listed in Table AII, together with an estimate of the yield level based on the expert land evaluation from the Digital Land Register. Agricultural areas used for short-rotation crops were not considered in this approach.

The estimation of forest potentials was based on existing forestry areas. The Digital Land Register served as a source for this spatial basis data. Since there was no geographic information available for the test region that distinguished between deciduous and coniferous forest, the regionally dominant coniferous type of forest was assumed for all areas. A volume of $10.7 \mathrm{~m}^{3}$ per ha of standing wood was assumed, which results in $8.92 \mathrm{~m}^{3}$ per ha after reductions for the bark and harvesting losses (Federal Forest Office, 2009) (Figure 4).

For the spatially explicit estimation of energy demand on a regional scale, heat demand was divided between that for households, for agriculture, and for commerce and industry. Several databases were evaluated, including available statistical data, information from chimney sweeps, municipality construction register data, and the Digital Land Register. Addresses with the associated building age, obtained from the municipal construction register, proved the most suitable data for estimating the heat demand of households as they provided spatially explicit and up to date information. The assumption that typical methods of construction that were employed over particular periods can be related to a specific heat demand is supported by the results of an empirical survey by Siller (2003), which showed that the construction period of buildings is associated with a specific heat demand. These energy indices represent the useful energy level and therefore include consumer behaviour. Our approach does not therefore exclusively define energy demand as the amount of energy required to provide particular products and/or services, but also takes into account variations in consumer behaviour and makes use of estimates of mean energy consumption. In order to estimate heat consumption by agriculture, in particular for warm water, a mean value of $14,000 \mathrm{kWh}$ per year per agricultural holding was assumed (Van Caenegem, 2009).

The heat demand for residential buildings and agriculture, [0] per address point, is given by equation (1):

$$
Q R A_{j}=\sum_{i} G F A R_{i, j} \cdot E R R_{i}+G F A R E_{i, j} \cdot E R R_{i} \cdot f+G F A A_{j} \cdot E R A \cdot f+Q A_{j}
$$




\section{IJESM}

6,1

\section{2}

\section{Figure 4.}

Spatial data and spatial modelling approaches
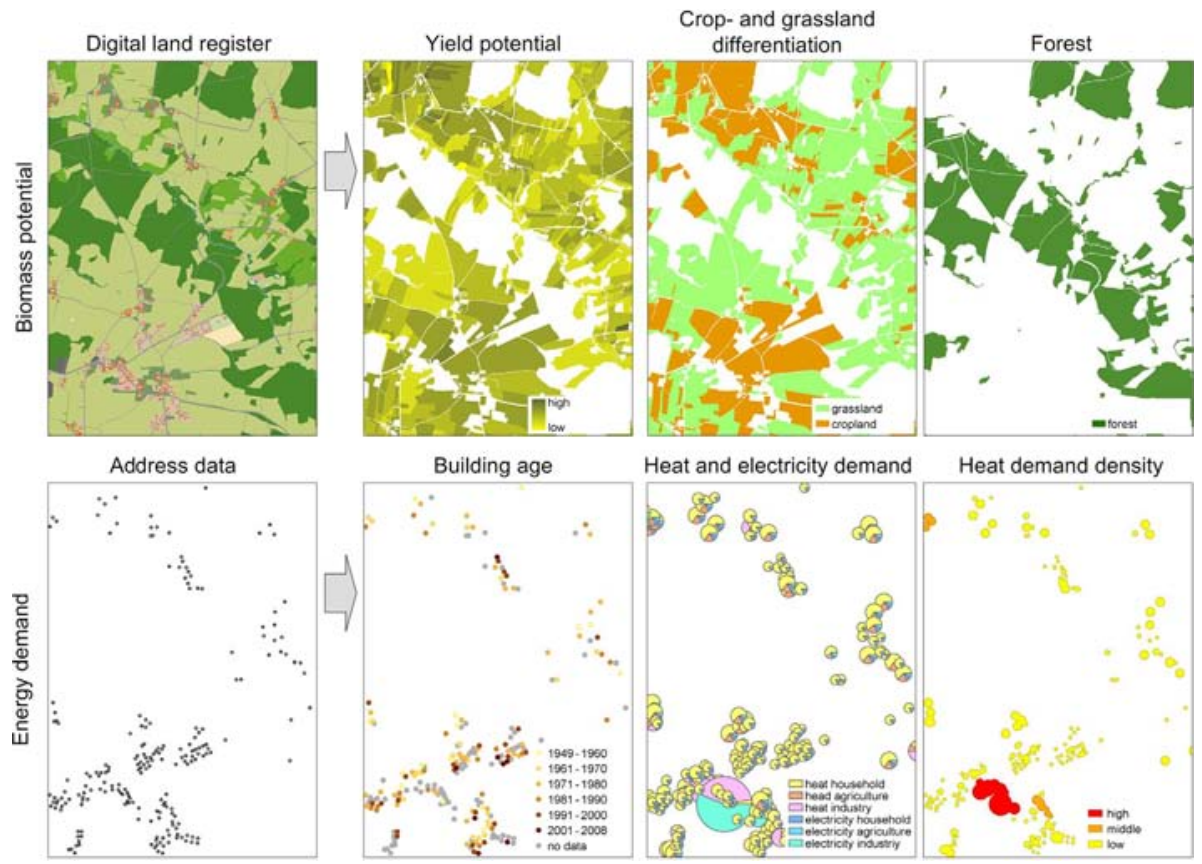

Heat and electricity demand Heat demand density

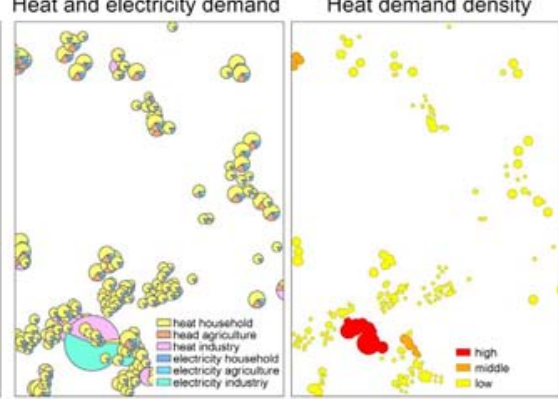

The heat demand for commerce and industry was calculated using unpublished indices that have been developed in an ongoing project of the Salzburg AG in cooperation with the Max Planck Institute for Plasma Physics. These indicators were adapted via heating degree days to regional climatic conditions and differentiated a specific energy demand per employee according to the NACE classification, which is a statistical classification of economic activities in the European Community.

The heat demand for commerce and industry, per address point, is given by equation (2):

$$
Q C D_{j}=\sum_{e s} E_{j, e s} \cdot E C_{j, e s} \frac{H D D t}{H D D r e f}
$$

The heat demand for residential buildings and agriculture was then added to that for commerce and industry, per address point, to derive the total heat demand per address point (equation (3)):

$$
Q_{j}=Q R A_{j}+Q C D_{j}
$$

\section{Notation.}

$Q R A_{j} \quad$ heat demand for residential buildings and agriculture, per address point (float value).

$G F A R_{i, j} \quad$ gross floor area of residential buildings (excluding agricultural residential buildings and reconstructed or extended buildings), per building period and address point (float value). 

$E R R_{i} \quad$ energy rating of residential buildings, per building period (float value).
$f \quad$ empirical factor for households, per address point (float value).

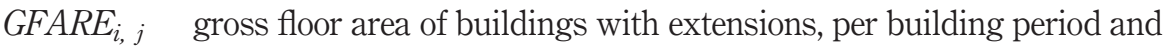 address point (float value).
GFAA, $\quad$ gross floor area of agricultural residential buildings, per address point (float value).
$E R A_{j} \quad$ energy rating for agricultural residential buildings, per address point (float value).
$Q A_{j} \quad$ heat demand for agriculture per address point (float value).
I $\quad$ building period (positive integer value).
$j \quad$ address point (positive integer value).
$Q C D_{j} \quad$ heat demand for commerce and industry, per address point (float value).
$E_{j}$, es number of employees per company, per economic sector and address point (integer value).
$E C_{j, \text { es }} \quad$ heat demand, per economic sector and address point (float value).
$H D D t \quad$ heating degree days for test region (float value).
HDDref heating degree days for reference energy demand (float value).
es $\quad$ economic sector (positive integer value).
$Q_{j} \quad$ heat demand, per address point (float value).

Areas that are potentially suitable for district heating are then identified and defined. A buffer is first calculated around the address points, with a diameter that relates to the heat demand for that particular address point. Overlapping buffer areas are then combined and the heat demand within these new areas is summed up. A heat demand density can thus be estimated and relevant areas for district heating can thus be identified and distinguished from single buildings or small groups of buildings.

For electricity demand we used the mean annual consumption per Austrian household of 4,417kWh (Statistics Austria, 2009) and a mean annual electricity demand for agriculture of $473 \mathrm{kWh}$ per ha (Botzenhart, 2007). Mean statistical values per employee and per NACE classification were assumed in order to estimate the electricity demand for services and industry.

\subsection{Linear optimisation}

The optimisation was conducted using the TIMES model generator. TIMES is an acronym for "The Integrated MARKAL-EFOM System", which generates optimisations of local, national or multi-regional energy systems. This tool serves as a technology-rich basis for estimating energy dynamics over a long-term, multi-period time horizon. The objective function of TIMES aims to supply energy services 


\section{IJESM}

6,1

14 at a minimum loss of surplus (Loulou et al., 2005a). Linear programming was chosen as an initial approach in order to keep the optimisation problem simple and to ensure that the global optimum was identified. The GAMS programming language was used to translate the TIMES database into a linear programming matrix and submit it to the optimiser. A CPLEX optimiser was used to solve the TIMES linear programming formulations (Loulou et al., 2005b). The defined RES was applied in the cost-based TIMES optimisation model.

The TIMES model generator was used as it is freely available and provides a ready-made model framework. The input data was fed into the TIMES model using the regional data derived from the GIS models and the assumptions on harvesting and on energy conversion processes, including investment and maintenance costs and assumptions on commodity prices. Spatial approaches were thus linked with the TIMES optimisation system. The time resolution of our model differentiated four seasonally typical days at four hourly intervals. The time frame covered ranged from 2010 to 2040 , with results presented in five-year steps.

The most important equations are listed below: some parameters have been omitted in order to present the equations in a streamlined form. Full details are listed in Loulou et al. (2005b); a more condensed version can be found in Loulou et al. (2005a).

The objective function (equation (4)) is minimised by the TIMES model (Loulou et al., 2005a):

$$
\operatorname{OBJ}(z)=\sum_{r=y}^{R} \sum_{1=Y \text { EARS }}\left(1+d_{r, y}\right)^{z-y} \cdot \operatorname{ANNCOST}(r, y)
$$

The annual costs consist of investment costs, taxes and subsidies on investments, decommissioning costs, fixed costs, taxes and subsidies on fixed costs, variable costs, elasticity costs, late revenues from recycling of materials from dismantled processes, and the salvage value of investments (equation (5)). The components of the annual costs are complex functions; there are, for example, four different investment cases considered, each of which is treated separately. The methods are fully described in Loulou et al. (2005b):

$$
\begin{aligned}
& \text { ANNCOST }(r, y) \\
& =\left(\begin{array}{l}
\operatorname{INVCOST}(r, y)+\operatorname{INVTAXSUB}(r, y)+\operatorname{INVDECOM}(r, y) \\
+\operatorname{FIXCOST}(r, y)+\operatorname{FIXTAXSUB}(r, y)+\operatorname{VARCOST}(r, y) \\
+\operatorname{ELASTCOST}(r, y)-\operatorname{LATEREV}(r, y)
\end{array}\right)-\operatorname{SALVAGE}(r, z)
\end{aligned}
$$

The TIMES model minimises the total discounted costs while satisfying a large number of constraints. The main constraints are listed below.

The use of capacity is given by equation (6):

$$
A C T(r, v, t, p, s) \leq o r=A F(r, v, t, p, s) \cdot \operatorname{CAPUNIT}(R, p) \cdot F R(r, s) \cdot C A P(r, v, t, p)
$$

The activity definition is given by equation (7):

$$
A C T(r, v, t, p, s)=\sum_{c} \frac{F L O W(r, v, t, p, c, s)}{A C T F L O(r, v, p, c)}
$$


The commodity balance is given by equation (8):

$$
\begin{aligned}
& {\left[\begin{array}{c}
\sum_{p, c \in T O P\left(r, p, c^{\prime \prime} \text { out" }\right)}(F, v, t, p, c, s) \\
\left.+\operatorname{SOUT}(r, v, t, p, c, s) \cdot S T G \_E F F(r, v, p)\right) \\
+\sum_{p, c \in R P C \_I R E\left(r, p, c^{\prime \prime} i m p "\right)}(\operatorname{TRADE}(r, t, p, c, s, " i m p "))
\end{array}\right] \cdot C O M \_I E(r, t, c, s) \geq o r} \\
& =\sum_{C, c \in P(r, p, c, " i n ")}(F L O W(r, v, t, p, c, s)+\operatorname{SIN}(r, v, t, p, c, s) \\
& +\sum\left(T R A D E\left(r, t, p, c, s, " \exp ^{\prime}\right)+F R(c, s) \cdot D M(c, t)\right. \\
& p, c \in R P C \_I R E(r, p, c, " \exp ")
\end{aligned}
$$

Notation for optimisation.

$O B J(z)$

$\operatorname{ANNCOST}(r, y)$

$d_{r, y}$

YEARS

$R$

$\operatorname{INVCOST}(r, y)$

$\operatorname{INVTAXSUB}(r, y)$

$\operatorname{INVDECOM}(r, y)$

$\operatorname{FIXCOST}(r, y)$

$\operatorname{FIXTAXSUB}(r, y)$

$\operatorname{VARCOST}(r, y)$

$\operatorname{ELASTCOST}(r, y)$

$\operatorname{LATEREV}(r, y)$

$\operatorname{SALVAGE}(r, z)$ total system cost, discounted to the beginning of year $z$ (float value).

total annual cost in region $r$ and year $y$ (float value). general discount rate (float value).

years for which there are costs, including all years within the time frame, plus past years (before the initial period) if costs have been defined for past investments, plus a number of years after end of the time frame where some investment and dismantling costs are still incurred, and also the salvage value (positive integer value).

set of regions in the area of study (positive integer value).

investment costs in region $r$ for year $y$ (float value).

taxes and subsidies on investments in region $r$ for year $y$ (float value).

decommissioning costs in region $r$ for year $y$ (float value).

fixed cost in region $r$ for year $y$ (float value).

taxes and subsidies on fixed costs in region $r$ for year $y$ (float value).

variable costs in region $r$ for year $y$ (float value).

elasticity costs in region $r$ for year $y$ (float value).

late revenues in region $r$ for year $y$ (float value).

salvage costs in region $r$ and reference year for discounting (float value). energy system

optimisation
Regional 
IJESM

6,1

16

activity level of technology $p$, in region $r$ for period $t$ (optionally vintage $v$ and time-slice $s$ ) (float value).

$A F(r, v, t, p, s)$

CAPUNIT $(r, p)$

$F R(r, s)$

$C A P(r, v, t, p)$

$\operatorname{FLOW}(r, v, t, p, c, s)$

$\operatorname{ACTFLO}(r, v, p, c)$

$T O P(r, p, c$, "out”)

$\operatorname{SOUT}(r, v, t, p, c, s)$

$S T G \_E F F(r, v, p)$

$R P C \_I R E(r, p, c$, ,imp”)

$\operatorname{TRADE}(r, t, p, c, s$, , imp”)

COM_IE $(r, t, c, s)$

$T O P(r, p, c$, in”)

$\operatorname{SIN}(r, v, t, p, c, s)$

$R P C \_I R E(r, p, c$, “exp”)

$\operatorname{TRADE}(r, t, p, c, s$, "exp”)

availability factor for technology $p$ in region $r$ for period $t$ (optionally vintage $v$ and time-slice $s$ ) (float value).

conversion factor between units of capacity and activity in region $r$, for technology $p$ (float value).

duration of time slice $s$ in region $r$ (float value).

fraction (less than or equal to 1) of the investment variable (float value).

conversion factor from the activity of the process $p$ to the flow of a particular commodity $c$ in region $r$ for period $t$ (optionally vintage $v$ and time-slice $s$ ) (float value).

conversion factor from the activity of process $p$ to the flow of commodity $c$ in region $r$ (optionally with vintage v) (float value).

output flow of commodity $c$ from process $p$ in region $r$ (float value).

quantity of commodity $c$ discharged by storage process $p$, in time-slice $s$, period $t$ (optionally with vintage $v$ ), and region $r$ (float value).

efficiency of storage process $p$ in region $r$ (optionally with vintage $v$ ) (float value).

import flow into region $r$ of commodity $c$ via process $p$ (float value).

quantity of commodity $c$ purchased by region $r$ through import process $p$ in period $t$ (optionally in time-slice $s$ ) (float value).

infrastructure efficiency of commodity $c$, period $t$ in region $r$ for time-slice $s$ (float value).

input flow of commodity $c$ into process $p$ in region $r$ (float value).

quantity of commodity $c$ stored by storage process $p$, in time-slice $s$, period $t$ (optionally with vintage $v$ ) and region $r$ (float value).

export flow from region $r$ of commodity $c$ via process $p$ (float value).

quantity of commodity $c$ sold by region $r$ through export process $p$ in period $t$ (optionally in time-slice $s$ ) (float value). 


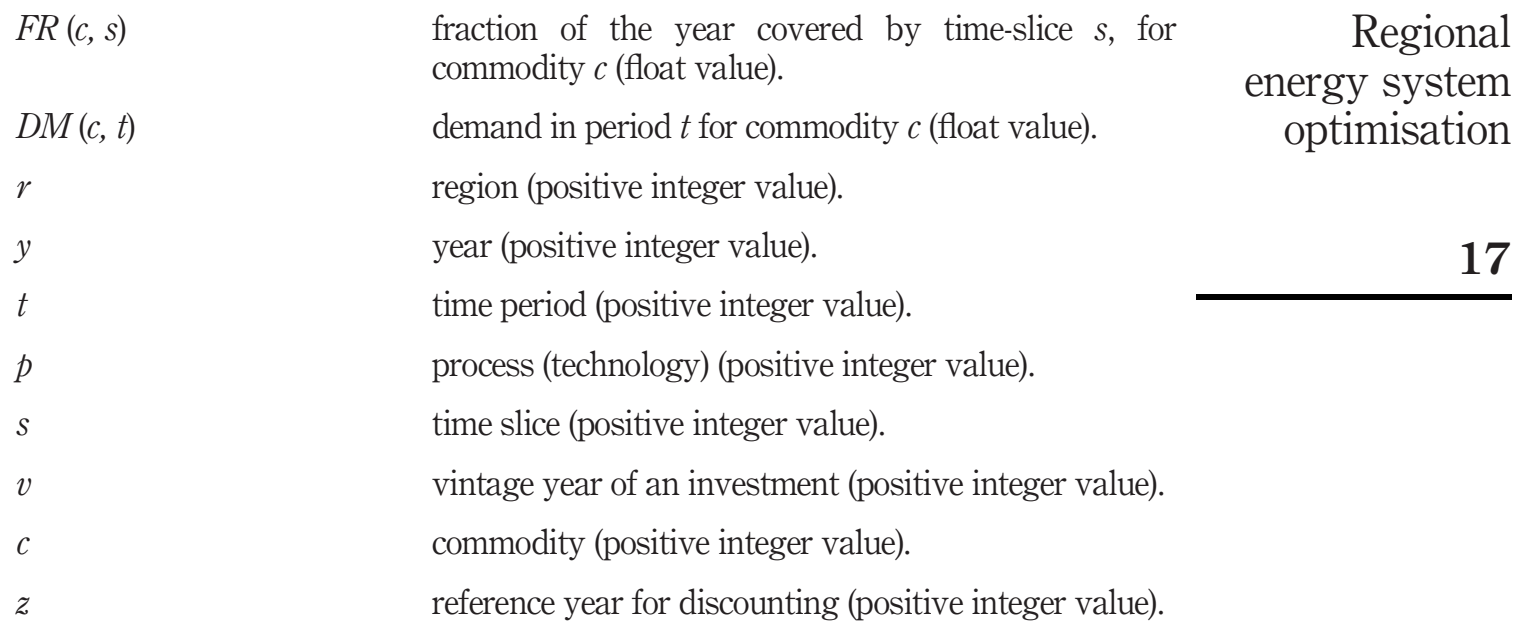

In total the model consists of 85,738 equations and 81,608 variables.

\section{Results of case studies}

\subsection{Structure of test regions}

The model developed was applied to the municipalities St Roman, in Austria, and Ungerhausen, in Bavaria, Germany. Both test regions are small rural municipalities (Table I).

Ungerhausen has a population density per $\mathrm{km}^{2}$ of agricultural and forest area more than three times as high as St Roman, and the total agricultural and forest area is also more than three times as great. A comparison of all municipalities in Bavaria and Austria shows the higher population density of Bavaria, which can be seen on the cartographical visualisation in Figure 5.

Figure 6 shows the yield index, which can range from 1 (very poor yield potential) to 100 (very high yield potential). The yield potentials of agricultural areas in the test municipalities reveal two quite different situations: Ungerhausen consists of a small

\begin{tabular}{llccl}
\hline & & St Roman & Ungerhausen & Units \\
\hline Inhabitants & & 1,800 & 1,064 & Persons \\
Area & Cropland & 704 & 235 & ha \\
& Grassland & 1,048 & 290 & ha \\
Livestock & Forest & 1,253 & 45 & ha \\
& Dairy cows & 1,600 & 570 & piece \\
& Beef cattle and calves & 2,240 & 470 & piece \\
Heating system & Pigs & 182 & 1,200 & piece \\
& Oil & 33.0 & 76.4 & $\%$ \\
& Gas & 0.0 & 17.5 & $\%$ \\
& Wood chips & 20.3 & 0.6 & $\%$ \\
& Split log & 38.5 & 0.6 & $\%$ \\
& District heating & 4.9 & 0 & $\%$ \\
& Others & 3.3 & 4.9 & $\%$
\end{tabular}

Source: Botzenhart (2007), Statistics Austria (2009), Digital Land Register, Municipal Office

Table I. Base data for test regions 


\section{IJESM}

6,1

18

Figure 5.

Population density in Austria and Bavaria

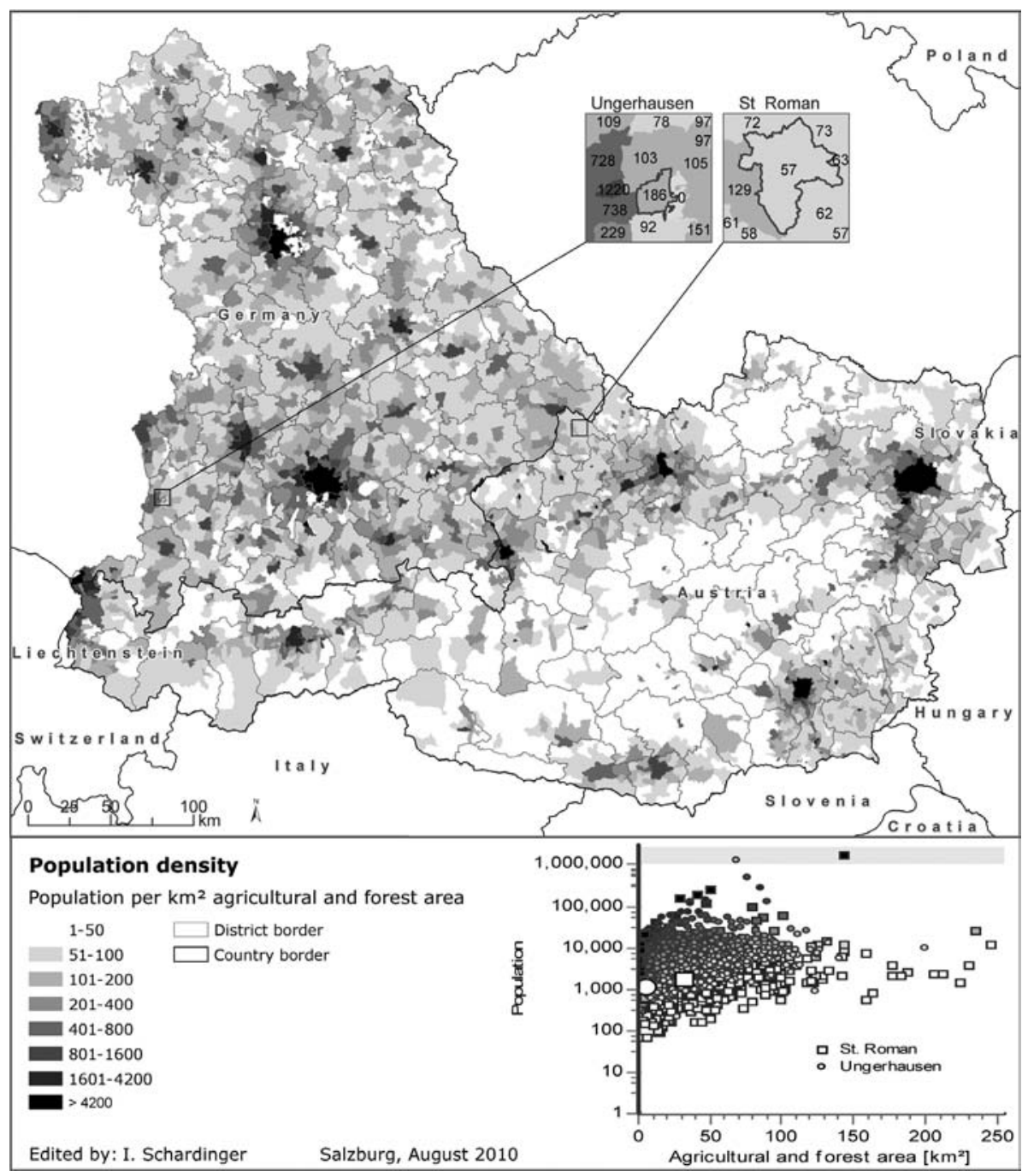

amount of area with very poor yield potential and large areas with high yield potential, while St Roman has large areas with low yield potential and only limited areas with higher yield potentials.

\subsection{Optimisation results}

Two different scenarios for each of the test regions were considered for the model run. Scenario 1 assumed no import of biomass, but other imported energy resources were unrestricted, Scenario 2 considered only energy resources from within the test region. A third scenario (Scenario 3) served for the sensitivity analysis (Table II). 
In our model approach the heat demand was assumed to remain constant at the present level for the whole of the modelled time frame. Increasing use of insulation is assumed to counteract the increase in heat consumption due to higher living standards. Electricity demand projections take into account higher living standards in the future and demand is assumed to rise over the model horizon. The projection is based on Redl et al. (2009).

Various aspects of the modelling results have been analysed. Figure 7 shows the total system costs for all scenarios. The results for Scenario 2 represent an energy system that is aiming for self-sufficiency. St Roman is theoretically able to meet its own energy demands, although at much higher costs since, for example, saw logs would need to be used for fuel. The total system costs would rise from $€ 27$ million to $€ 34$ million. In contrast, a restriction to regional energy resources in Ungerhausen would lead to an infeasible optimisation problem. Scenario 1 would result in total system costs of $€ 49$ million for the Ungerhausen test region.

The heat mix, electricity mix, and the $\mathrm{CO}_{2}$ emissions for the current situation, Scenarios 1 and 2 in the St Roman test region are shown in Figure 8, while Figure 9 shows the results for

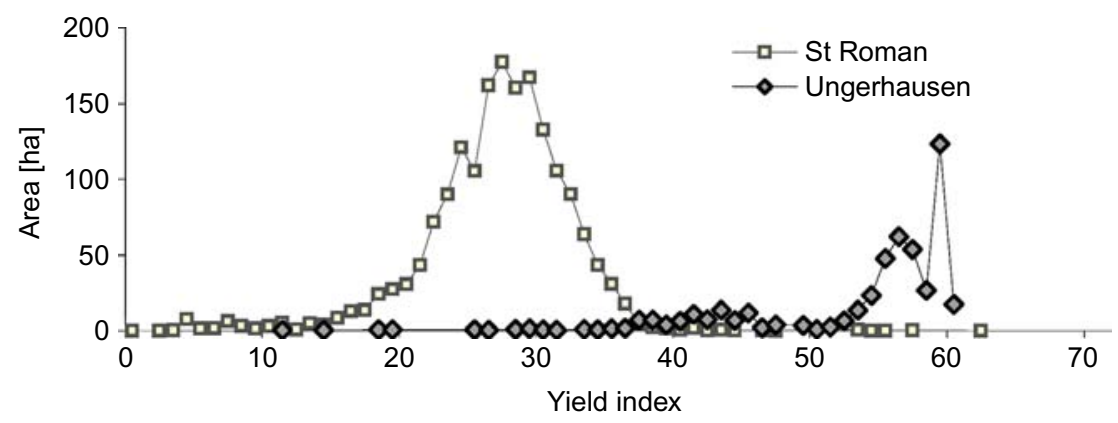

Figure 6. Yield structure of agricultural areas

\begin{tabular}{llll}
\hline & Scenario 1 & Scenario 2 & Scenario 3 \\
\hline $\begin{array}{l}\text { Import of energy } \\
\text { resources }\end{array}$ & No biomass import & No import of energy resources & No biomass import \\
$\begin{array}{l}\text { Fuel oil prices } \\
\text { Test regions }\end{array}$ & St.37/lt in 2040 & $€ 1.37 / 1$ in in 2040 & Sensitivity analysis \\
& St Ungerhausen & St Roman Ungerhausen & St Roman
\end{tabular}

Figure 7. Total system costs for all scenarios

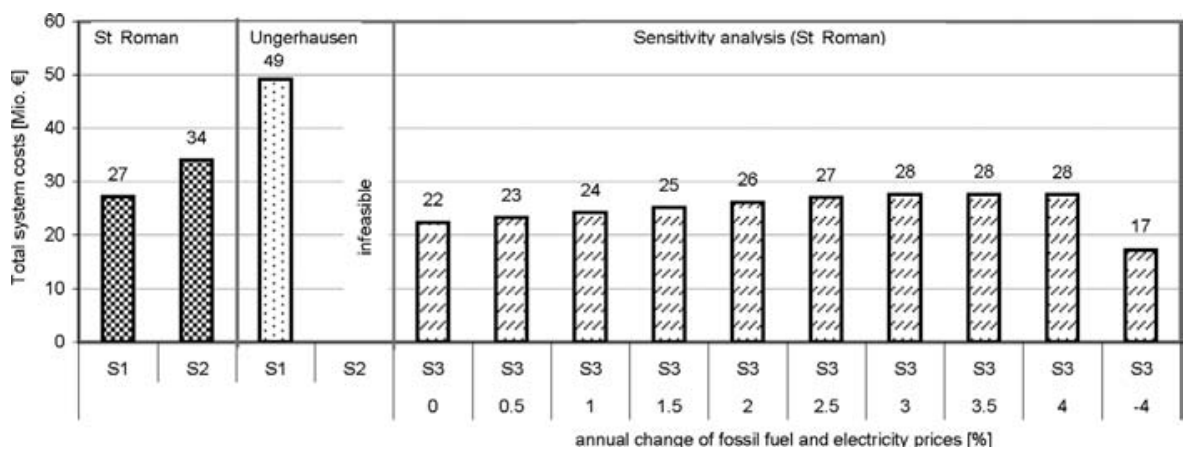

Table II. Scenarios 


\section{IJESM}

6,1

20

the Ungerhausen test region. The current heat supply for the St Roman test region is predominantly based on biomass, which can be explained by the relatively large areas of forest. St Roman has a mean population density per $\mathrm{km}^{2}$ of forest area of 144, compared to 2,364 for Ungerhausen where the regional heat supply is based on fossil fuels (oil and gas). The figures also show the different demand structures. The St Roman test region has a higher total energy demand and a higher proportion of single buildings and small villages for which district heating is not feasible, while the Ungerhausen test region has a more dense settlement structure and therefore a higher proportion of demand can be met by district heating options. The heat mix in all scenarios is heading towards increasing use of biomass.

Both test regions show high import dependencies for their supplies of electricity. The Ungerhausen test region, however, produces a high proportion of photovoltaic electricity in addition to the electricity that it imports. Scenario 2 shows that St Roman could theoretically meet its own electricity demand.

Since the high proportion of biomass fuel and the sharply decreasing emissions are exceptional in both Scenarios 1 and 2, a sensitivity analysis was used to investigate these results. Fossil fuel and external electricity prices were analysed with respect to their effects on the $\mathrm{CO}_{2}$ emissions and the proportion of renewables. The assumptions for Scenarios 1 and 2 regarding fuel oil prices rising to $€ 1.37$ per 1 in 2040 follow the predictions of the US Energy Information Administration (2009). The sensitivity analysis was carried out for the St Roman test region and the results are shown in Figure 10.

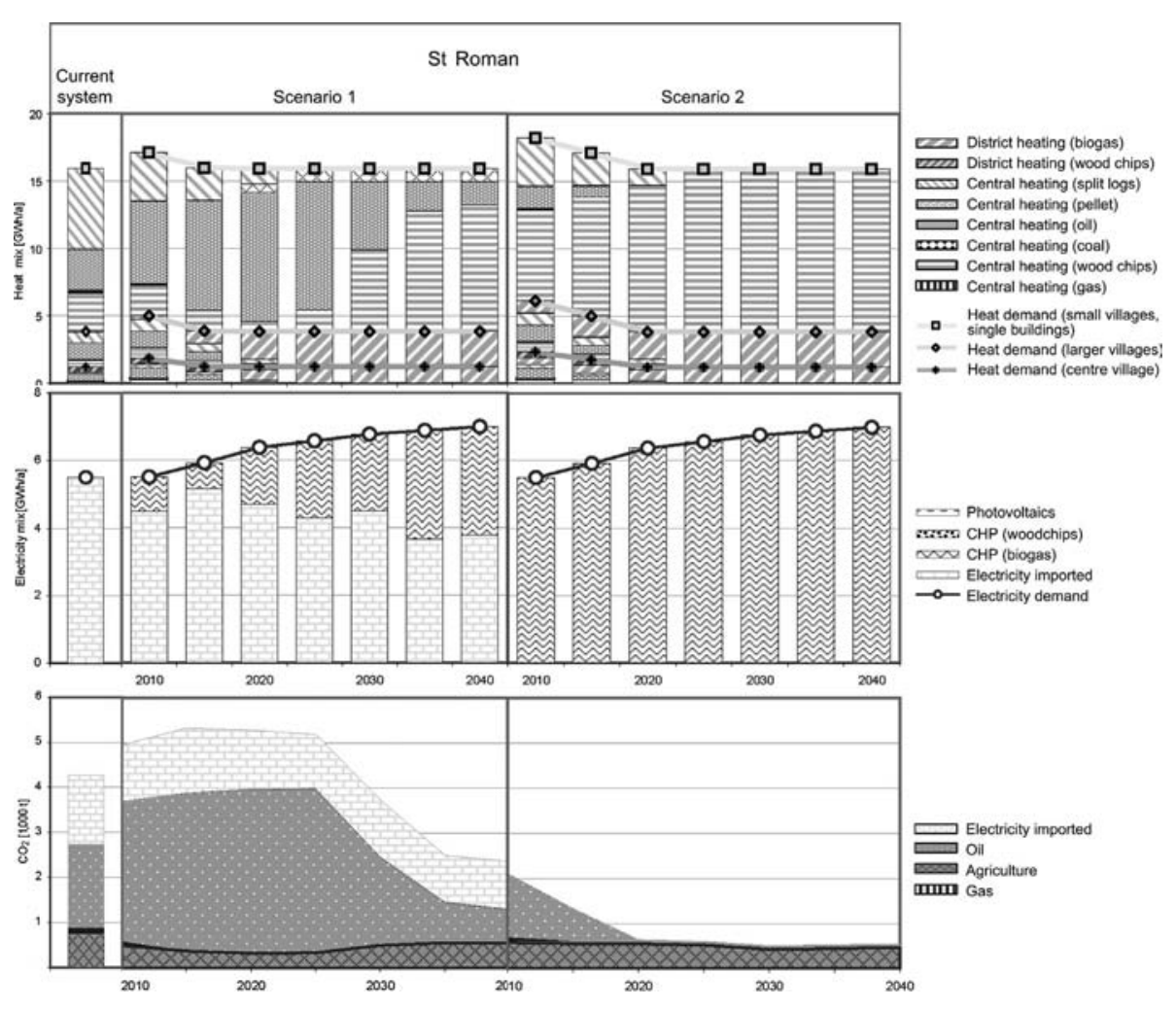

Figure 8.

Heat mix, electricity mix, and $\mathrm{CO}_{2}$ emissions for Scenarios 1 and 2 in the St Roman test region 

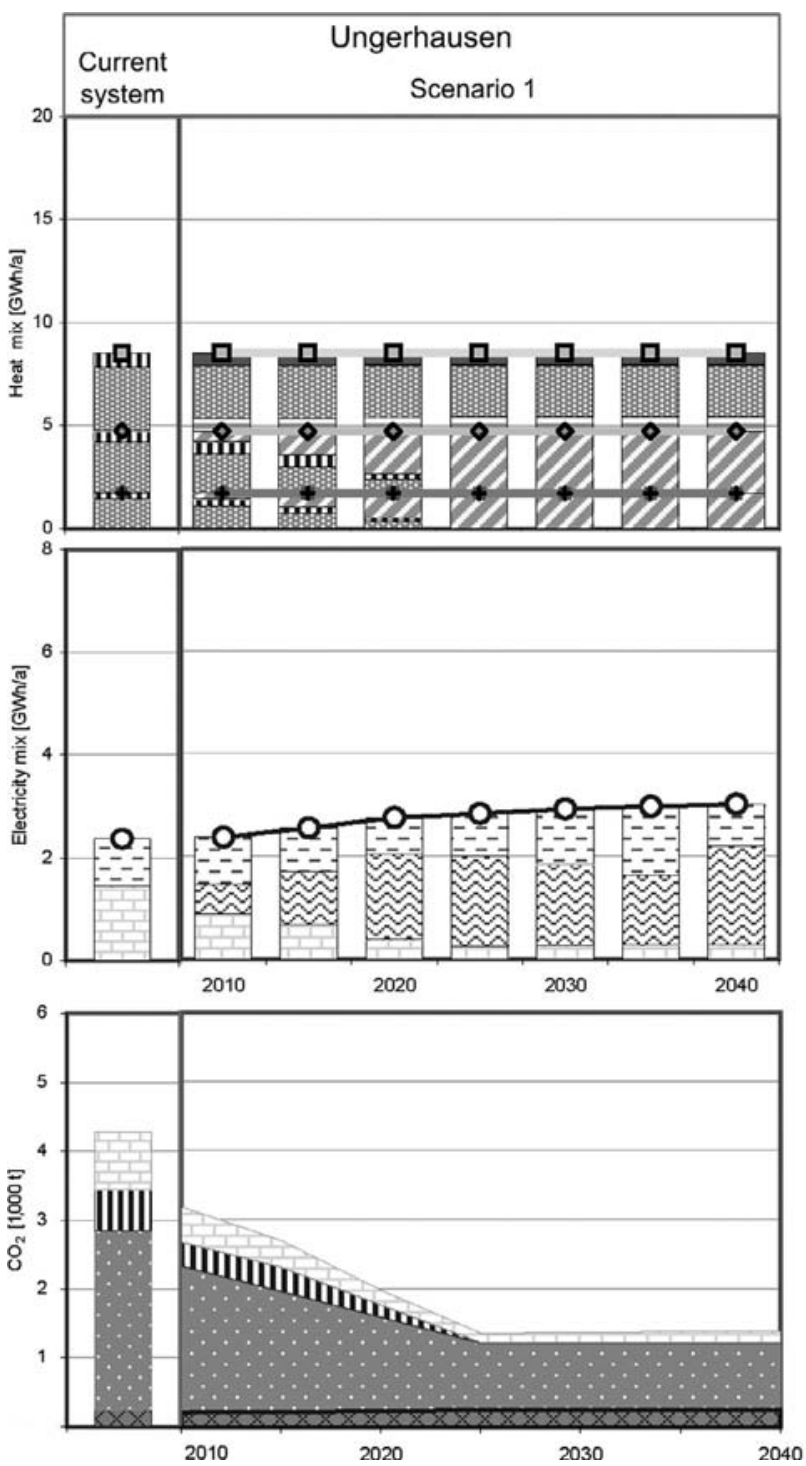

District heating (biogas)

एum District heating (wood chips)

Central heating (split logs)

Central heating (pellet)

$\square$ Central heating (oil)

Central heating (coal)

Central heating (wood chips)

IIIII) Central heating (gas)

Heat demand (small villages, - single buildings)

- Heat demand (larger villages)

- Heat demand (centre village)

\section{$\Longrightarrow$ Photovoltaics}

axtes CHP (woodchips)

लHP (biogas)

$\square$ Electricity imported

-

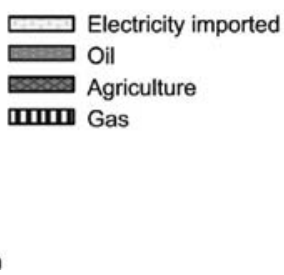

Regional energy system optimisation

21
Figure 9.

Heat mix, electricity mix, and $\mathrm{CO}_{2}$ emissions for Scenarios 1 and 2 in the Ungerhausen test region

Scenario 3 shows that an annual price increase of 2 and 2.5 per cent for fossil fuels and external electricity supplies, respectively, would lead to a significant change in the system: the proportion of renewables would increase to 85 per cent and, at the same time, $\mathrm{CO}_{2}$ emissions would decrease markedly. This appears to suggest that the modelled renewable sources, which are mostly based on biomass, would be economically competitive if fossil fuel prices were to rise as shown. Limitations on the use of biomass can be related to regional availability of suitable land areas for their cultivation. The sensitivity analysis also considered a decrease in fossil fuel and electricity prices of 4 per cent per year. 


\section{IJESM \\ 6,1}

22

The corresponding results show a decline of the proportion of renewables and a rise in $\mathrm{CO}_{2}$ emissions. Scenarios 1 and 2 for the test regions assume large increases in fossil fuel prices and the radically changes to the energy system that they predict to the year 2040 correspond with the results from the sensitivity analysis for high fossil fuel and electricity prices. Technology costs and demand developments are also assumed to have high impacts on the system. These impacts and other factors affecting the regional energy system are subject to ongoing research.

In an additional step the scenario results for land use of St Roman test region were spatially disaggregated, for which the investigated area was divided into a $250 \mathrm{~m}$ grid. The agricultural lot areas per grid cell for each yield potential class were then totalled and cumulative land use proportions per yield potential class applied to the available areas per grid cell, for each municipality. This results in grid cells containing a majority of lots with high yield potentials having a high proportion of the total used area (Figures 11 and 12).

Areas with a high proportion of lots with low yield potentials produced cells with a higher proportion of unused areas (Figure 11). For forestry the total proportion of energy and material use was applied to the area of forest per grid cell. Figure 12 shows the results for Scenario 2, with a high proportion of agricultural and forest area used for energy production. In contrast, Scenario 1 (Figure 11) has a lower proportion used for energy production. One reason for the existence of areas with no use can be that the model does not include subsidies, either for agriculture or for feed-in tariffs. Scenario 1 is based on a pure cost optimisation without any further constraints, and the assumed market prices for agricultural products may therefore result in fallow land, especially in lots with low yield potentials.

The model was validated by comparing the results from Ungerhausen with those obtained by applying the model from Botzenhart (2007) to the Ungerhausen region. Figure 13 shows the results for energy carriers of heat production and the $\mathrm{CO}_{2}$ emissions of the reference model. Several differences can be observed between the two models. The total heat demand of the reference model is lower as the whole municipality was not considered and only oil-based central heating technologies were included. The fuel oil price projection involved an increase of 2 per cent per year and a price of $€ 0.91$ per lt in the year 2040, which is lower than the price used in our approach. In addition, the agricultural land available for biogas production was restricted to land that was not in use. These are some of the main differences between the assumptions used for the two models.

Figure 10.

Sensitivity analysis changes in fossil fuel and electricity prices: 2040 results for Scenario 3, St Roman

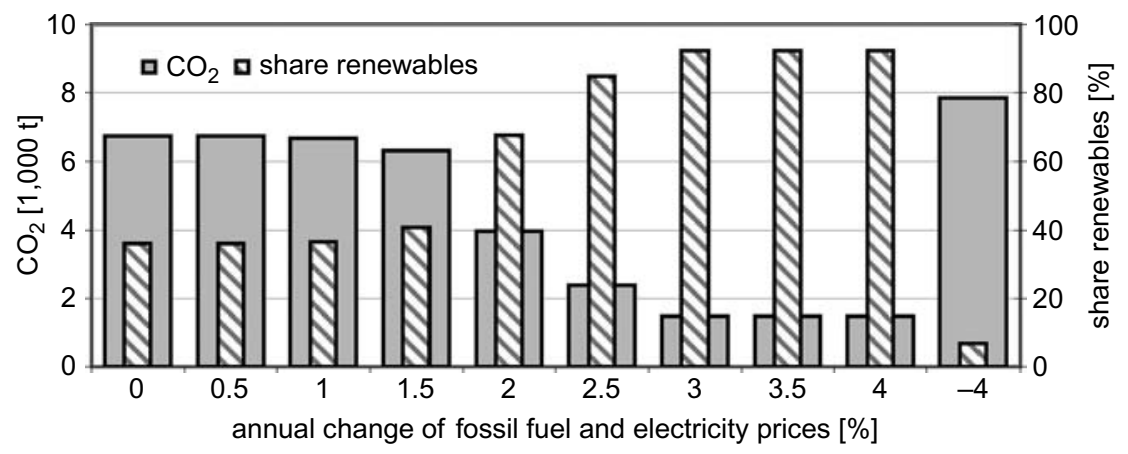




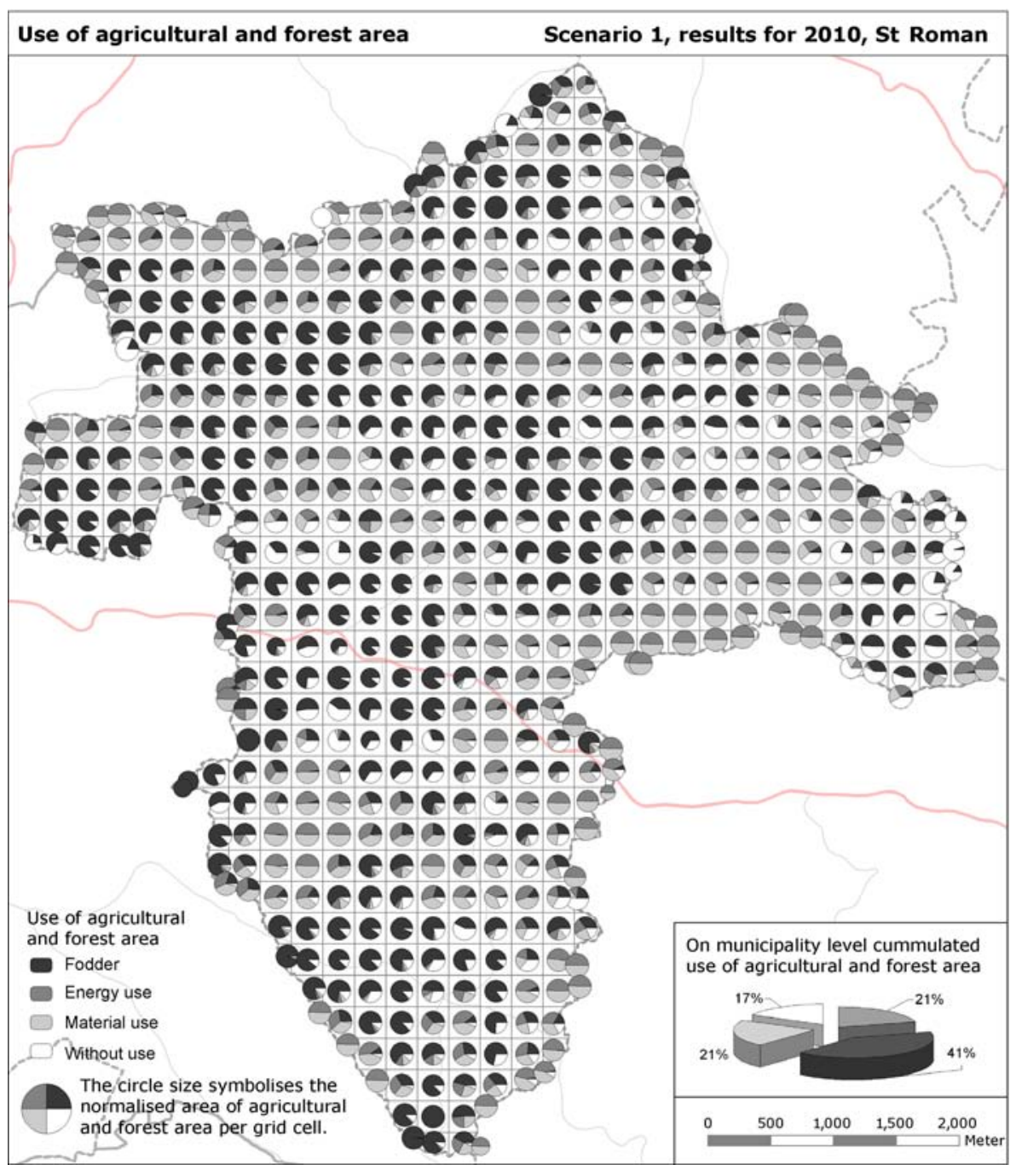

\section{Regional energy system optimisation}

Figure 11. Spatial disaggregation Scenario 1

The assumptions of our model were adapted to the reference approach for the purpose of the validation. The model run with the adapted assumptions yielded results that approximated those obtained using the model from Botzenhart (2007). Further validations of the model and of model components such as the biomass yield potentials, are the subject of ongoing projects and are expected to enhance the optimisation approach presented in this paper.

\section{Discussion}

The methodology presented in this paper has positive implications for research as it broadens the envelope of energy system modelling by including agricultural and land use components. The presented optimisation model demonstrates that the methods 


\section{IJESM}

6,1

24

Figure 12.

Spatial disaggregation Scenario 2

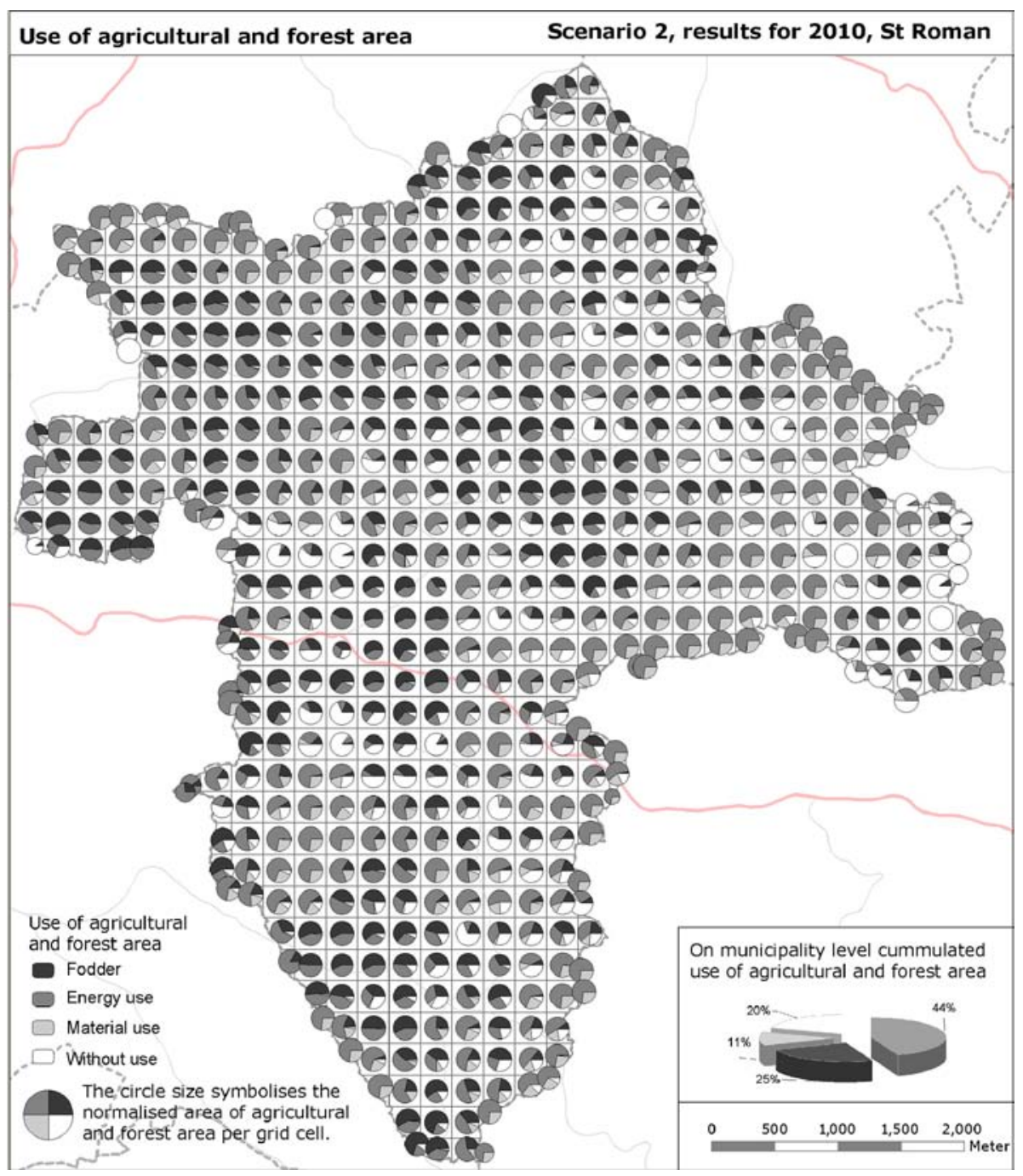

of energy system modelling can be applied to agricultural systems. Agricultural processes such as harvesting and husbandry can be defined in the same way as energy conversion processes, taking into account investment costs, variable costs, efficiencies, $\mathrm{CO}_{2}$ emissions, input commodities, output commodities, lifetime of asset invested, etc. This allows an integration of the agricultural system into the energy system and both systems can hence be analysed within a single integrated model. This initial approach was formulated as a linear optimisation problem, enabling the use of straightforward modelling. Binary variables will need to be considered if the model is to be further advanced.

Spatial models can provide regional data as input into the optimisation model in order to take into account regional conditions and to make the optimisation model 
easily transferable. The quality of available regional data clearly affects the achievable accuracy of the model results. Privacy constraints and data politics can restrict access to data, especially to information concerning buildings in areas characterised by low settlement density. The estimation of energy demand based on building ages therefore serves only as a first approximation. Further enhancements to demand estimation based on more detailed building data are a work in progress. Further development potential for the model is seen to lie in evaluation of the process chains and evaluation of the biomass growth model. These topics will be subject of follow-up projects.

The results of the case studies show that use of biomass for energy supply is largely a question of biomass availability. Assuming no imports and no use of high quality forest products, potential biomass resources are not sufficient to meet the regional heat demand, even in rural areas with considerable areas of forest. The modelled energy system developments are greatly influenced by fossil fuel price assumptions, as shown in the sensitivity analysis. Strong influences from technology costs and demand development are also expected and these interrelationships will need to be analysed in the future. District heating is evaluated by the model as being the most economic option. The scenarios do not consider heat demand reduction over the modelled time scale, which could, for example, be achieved by improving the insulation of buildings. Lower heat demand however has impacts on the choice of energy conversion technologies. District heating in particular is affected by lower energy consumption of individual buildings. As a sustainable energy system requires both a reduction of consumption and an increase in the use of renewable energy, work on extensions of the model to take into account improvements in construction is ongoing.

The developed model provides an overview of interrelationships between the energy and agricultural systems; it is both flexible and extendable, and adding further aspects such as electricity grid costs may produce variations in the results.

The use of spatial data-sets as input in a bottom-up forecast model approach has been evaluated and model outcomes have been geographically interpreted. The methodology presented creates added value as it is easily transferable to other regions and demonstrates that publicly available data is accessible as reliable input data. This is an innovative approach and the current paper provides an initial insight into the linking of optimisation with geographic domains.

The model developed has positive implications for society as it can assist decision-makers with long-term energy planning and land use policy. Energy planners are able to obtain an insight into energy infrastructure requirements, and land use policy

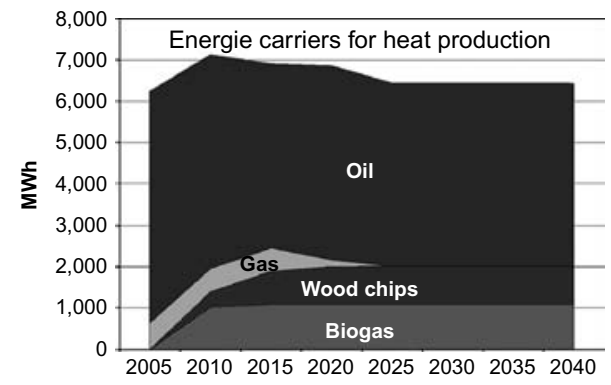

Source: Botzenhart (2007)

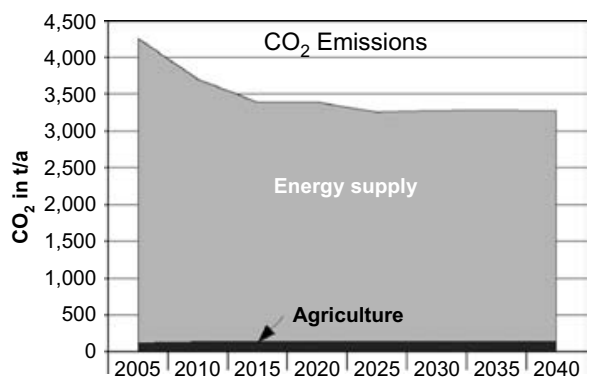
by energy carriers and the

$\mathrm{CO}_{2}$ emissions of the reference model 


\section{IJESM}

6,1 can better take into account energy resource options. The model also allows energy matrices to be identified that can both meet demand and satisfy $\mathrm{CO}_{2}$ emissions targets. The case studies demonstrate that regions can achieve a particular level of self-sufficiency via renewable resources, under appropriate economic conditions. This can help to stimulate indigenous economic activity and strengthen the regional purchasing power by reducing import bills. Stimulated economic activities by linking the agriculture/forestry and energy sectors may also include positive effects in terms of local employment opportunities.

\section{Acknowledgements}

The work presented in this paper has been carried out within a project entitled "Geographic data and methods as a basis for energy system optimisation with a focus on biomass", financed by the Friedrich Schiedel Foundation for Energy Technology. This project is realised in cooperation between the Max-Planck-Institute for Plasmaphysics in Garching, Germany and the Studio iSPACE from the Research Studios Austria Forschungsgesellschaft mbH.

\section{References}

Alfonso, D., Perpiñá, C., Pérez-Navarro, A., Peñalvo, E., Vargas, C. and Cárdenas, R. (2009), "Methodology for optimization of distributed biomass resources evaluation, management and final energy use", Biomass and Bioenergy, Vol. 33 No. 8, pp. 1070-9.

Berndes, G., Hoogwijk, M. and van den Broek, R. (2003), "The contribution of biomass in the future global energy supply: a review of 17 studies", Biomass and Bioenergy, Vol. 25 No. 1, pp. 1-28.

Biberacher, M. (2007a), Fusion in the Global Energy System - GIS and TIMES, Ciemat, Madrid.

Biberacher, M. (2007b), Modelling and Optimisation of Future Energy Systems Using Spatial and Temporal Methods, VDM Verlag Dr Müller, Saarbrücken.

BMLFUW (2008), Deckungsbeiträge und Daten für die Betriebsplanung 2008, Federal Ministry of Agriculture, Forestry, Environment and Water Management, Vienna.

Botzenhart, F. (2007), Optimal Utilization of Solar Energy under Thermodynamic and Economic Perspectives, Max-Planck-Institute for Plasma Physics, Garching.

Buchgraber, K. (2007), Die Nachfrage nach Energie belebt auch die Grünland-und Viehwirtschaft, Ländlicher Raum, Online Journal of the Federal Ministry of Agriculture, Forestry, Environment and Water Management, Vienna.

Buchgraber, K., Resch, R. and Blaschka, A. (2003), "Entwicklung, Produktivität und Perspektiven der österreichischen Grünlandwirtschaft", paper presented at 9. Alpenländisches Expertenforum, 27-28 March, Irdning, available at: www.raumberg-gumpenstein.at/c/ index.php?option $=$ com_docman\&task=cat_view\&gid=48\&Itemid=100103 (accessed 28 October).

Connolly, D., Lund, H., Mathiesen, B.V. and Leahy, M. (2010), "A review of computer tools for analysing the integration of renewable energy into various energy systems", Applied Energy, Vol. 87 No. 4, pp. 1059-82.

Dominguez, J. and Amador, J. (2007), "Geographical information systems applied in the field of renewable energy sources”, Computers \& Industrial Engineering, Vol. 52 No. 3, pp. 322-6.

Dorfinger, N. (2007), GIS unterstützte Vergleichsanalysen von Energieholzpotenzialen mit regionalen Wärmeverbrauchskosten, Karl-Franzens-Universitaet Graz, Graz.

Eherer, C. and Baumann, M. (2004), Fusion as a New Energy Technology in a Long-term TIMES Model of an Energy System, Karl-Franzens-Universitaet Graz, Graz. 
Federal Forest Office (2009), "Ergebnisse der Österreichischen Waldinventur 2000-2002", available at: http://web.bfw.ac.at/i7/Oewi.oewi0002?geo $=4 \&$ isopen $=0 \&$ display_page $=0$ (accessed 28 October).

Graham, R., English, B. and Noon, C. (2000), "A geographic information system-based modelling system for evaluating the cost of delivered energy crop feedstock", Biomass and Bioenergy, Vol. 18 No. 4, pp. 309-29.

Graham, R., Liu, W., Downing, M., Noon, C., Daly, M. and Moore, A. (1997), "The effect of location and facility demand on the marginal cost of delivered wood chips from energy crops: a case study of the state of Tennessee", Biomass and Bioenergy, Vol. 13 No. 3, pp. 117-23.

Guggenberger, T. and Blaschka, A. (2009), "Satellitengestützte Almbewertung - Potenziale und Risiken alpiner Weideflächen”, in Strobl, J., Blaschke, T. and Griesebner, G. (Eds), Angewandte Geoinformatik 2009. Beiträge zum 21. AGIT Symposium Salzburg, Herbert Wichmann, Heidelberg, pp. 526-35.

Hrbek, R., Freyer, B., Amon, T. and Friedel, J.K. (2007), "Nachhaltige Fruchtfolgesysteme für den konventionellen Energiepflanzenbau in Österreich", in Herrmann, A. and Taube, F. (Eds), Mitteilungen der Gesellschaft für Pflanzenbauwissenschaften, Vol. 19, Schmidt \& Klaunig KG, Kiel, p. 203, available at: www.gpw.uni-bonn.de/pdf/publikation/Tagungsband 2007_ Homepage.pdf (accessed 3 January).

Kalt, G., Kranzl, L. and Haas, R. (2010), "Long-term strategies for an efficient use of domestic biomass resources in Austria”, Biomass and Bioenergy, Vol. 34 No. 4, pp. 449-66.

Leonhartsberger, C. (2008), "Nachhaltige Fruchtfolgen im Energiepflanzenanbau", paper presented at Seminar für Biogas-SpezialberaterInnen, 23 October, Linz, Austria, available at: http://res.dada.at/oekl/gems/LeonhartsbergerBiogas081023.pdf (accessed 28 October).

Loulou, R., Remne, U., Kanudia, A., Lehtila, A. and Goldstein, G. (2005a), Documentation for the TIMES Model: PART I, available at: www.etsap.org/Docs/TIMESDoc-Intro.pdf (accessed 28 October).

Loulou, R., Remne, U., Kanudia, A., Lehtila, A. and Goldstein, G. (2005b), Documentation for the TIMES Model: PART II, available at: www.etsap.org/Docs/TIMESDoc-Details.pdf (accessed 28 October).

Masera, O., Ghilardi, A., Drigo, R. and Trossero, M.A. (2006), "WISDOM: a GIS-based supply demand mapping tool for woodfuel management”, Biomass and Bioenergy, Vol. 30 No. 7, pp. 618-37.

Mittlböck, M. et al. (2006), "Virtuelle Kraftwerke für autarke Regionen”, in Federal Ministry for Transport, Innovation and Technology (Ed.), Berichte aus Energie und Umweltforschung, Vol. 58, Vienna.

Mühlich, P., Botzenhart, F., Braun, S. and Hamacher, T. (2009), "A TIMES model as a means of local network planning”, paper presented at IEW Meeting 2009, Venice, Italy, available at: www.iccgov.org/iew2009/speakersdocs/presentazioni/19.06.2009/Paralle19/Pascal\% 20MUEHLICH.ppt.pdf (accessed 29 June).

Nagel, J. (2000), "Determination of an economic energy supply structure based on biomass using a mixed-integer linear optimization model”, Ecological Engineering, Vol. 16 No. 1, pp. 91-102.

Ordecsys, Kanors, Haloa and Kul (2004), "EFDA World TIMES Model”, Final Report.

Paar, M. and Nowak, H. (1991), "Energetische Nutzung von Stroh”, in Umweltbundesamt (Ed.), UBA-BE-003 Berichte, available at: http://umweltbundesamt.at/aktuell/publikationen/ publikationssuche/publikationsdetail/? \&pub_id=597 (accessed 28 October). 


\section{IJESM}

6,1

28

Prinz, T., Biberacher, M., Gadocha, S., Mittlböck, M., Schardinger, I., Zocher, D., Riedler, W., Strasser, H., Fackler, A., Dorfinger, N. and Obersteiner, M. (2009), "Energie und Raumentwicklung. Räumliche Potenziale erneuerbarer Energieträger”, Austrian Conference on Spatial Planning (ed.), Institution Series No 178, Vienna.

Redl, C., Müller, A. and Haas, R. (2009), "Langfristige Szenarien der österreichischen Stromversorgung", paper presented at IEWT 2009, Vienna, Austria, available at: http:// eeg.tuwien.ac.at/eeg.tuwien.ac.at_pages/events/iewt/iewt2009/papers/3B_2_REDL_C_P. pdf (accessed 15 December).

Rentizelas, A.A., Tatsiopoulos, I.P. and Tolis, A. (2009), “An optimization model for multi-biomass tri-generation energy supply”, Biomass and Bioenergy, Vol. 33 No. 2, pp. 223-33.

Schardinger, I., Biberacher, M. and Gadocha, S. (2008), "GIS-based location decision support model for biogas plants considering local supply and demand", in Schnitzer, H. and Ulgiati, S. (Eds), Advances in Energy Studies. Towards a Holistic Approach Based on Science and Humanity, Verlag der Technischen Universität Graz, Graz.

Siller, R. (2003), Energie-und CO2-Bilanz der Klimabündnisgemeinde St Johann im Pongau, Karl-Franzens-Universitaet Graz, Graz.

Statistics Austria (2009), Statistische Nachrichten Juni 2009, Österreich GmbH, Vienna.

US Energy Information Administration (2009), Annual Energy Outlook 2009, Washington DC, available at: http://eia.doe.gov/oiaf/aeo/pdf/0383(2009).pdf (accessed 3 January).

Van Caenegem, L. (2009), "Bauliche Gestaltung von Melkständen - Berücksichtigungen in der Bauplanung", paper presented at 2. Tänikoner Melktechniktagung, Ettenhausen, Switzerland, 25-26 March, available at: http://agroscope.admin.ch/veranstaltungen/ 00106/index.html?lang (accessed 28 October).

Yamamoto, H., Fujino, J. and Yamaji, K. (2001), "Evaluation of bioenergy potential with a multi-regional global-land-use-and-energy model”, Biomass and Bioenergy, Vol. 21 No. 3, pp. 185-203.

\section{Appendix}

Table AI.

Abbreviations

\author{
Anno \\ Carbon dioxide \\ Euro \\ Figure \\ Geographic Information Systems \\ Hectare \\ Kilogram \\ Kilowatt \\ Kilowatt peak \\ Kilowatt hour \\ Kilowatt hour - thermal \\ Kilowatt hour - electric \\ Square metre \\ Cubic metre \\ Reference energy system \\ Litre \\ Ton \\ The integrated MARKAL-EFOM system
}




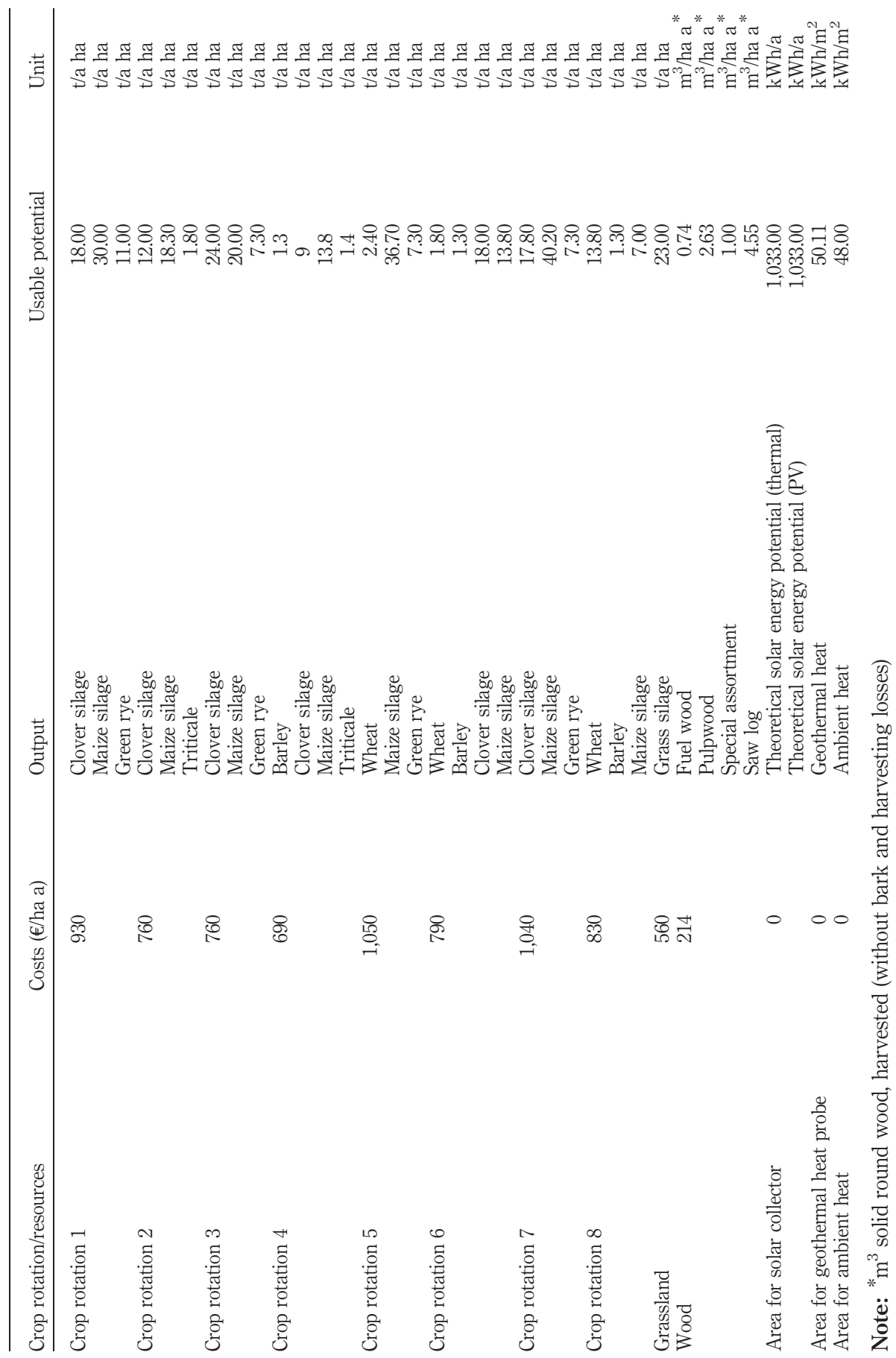

\section{Regional energy system optimisation}

29

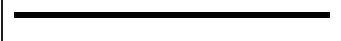

Table AII. Yield data used in the optimisation model 


\section{IJESM \\ 6,1}

30

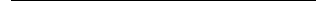

Table AIII.

Husbandry data used in the optimisation model

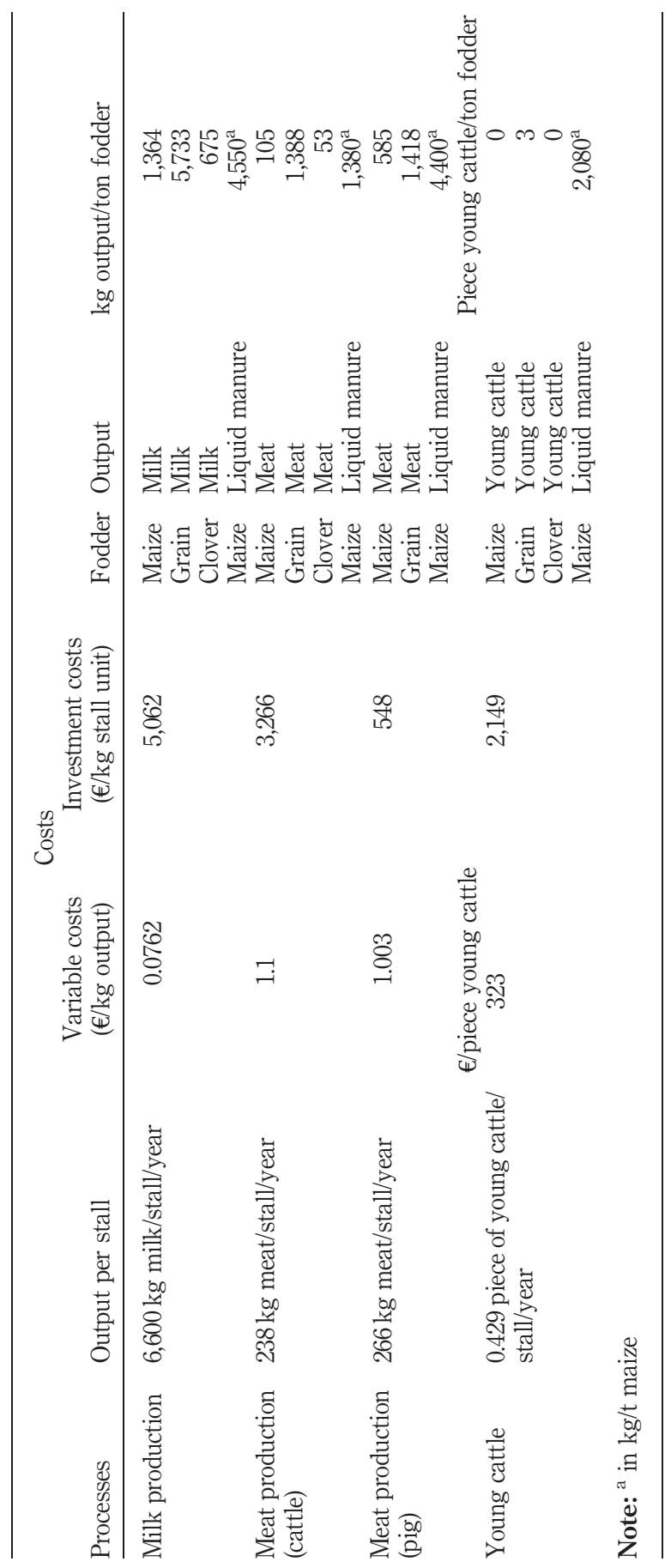




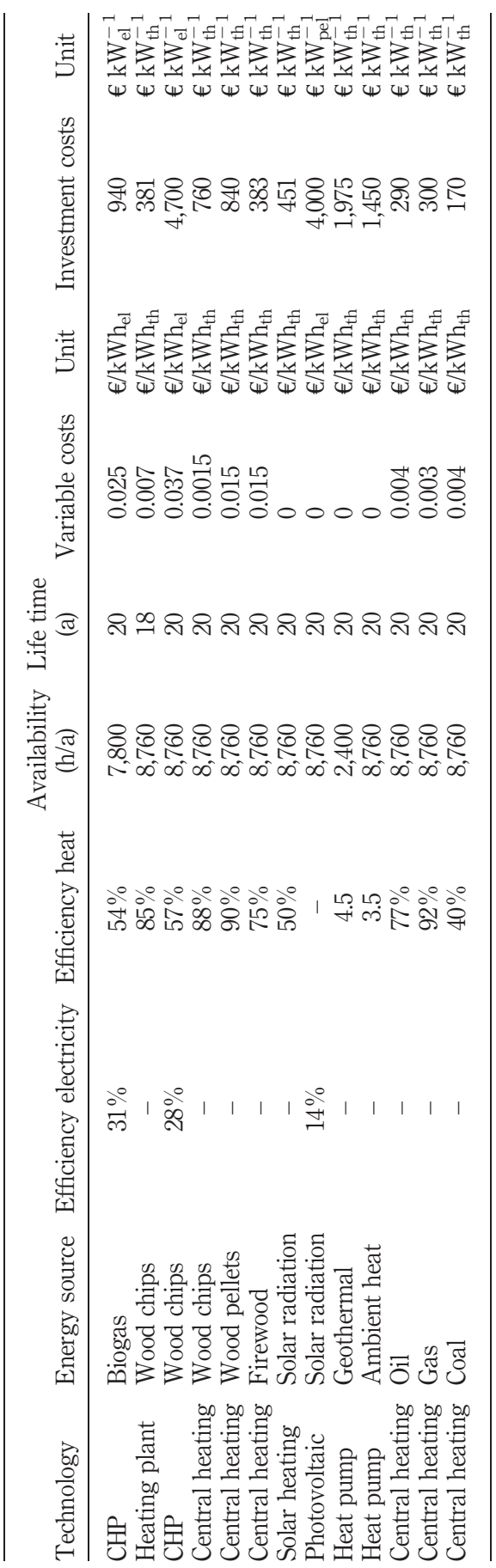




\section{IJESM 6,1}

32

\section{About the authors}

Ingrid Schardinger is a Junior Researcher at Studio iSPACE, Research Studios Austria Forschungsgesellschaft $\mathrm{mbH}$, Salzburg, Austria and has been a $\mathrm{PhD}$ student at the Geography Department (Applied Geoinformatics), University of Salzburg since 2009. She undertook her Master of Applied Geoinformatics studies at the University of Salzburg (2005-2007), obtaining her Master degree in 2007. Her thesis title was "GIS based location decision support model for biogas plants considering local supply and demand". Ingrid Schardinger is the corresponding author and can be contacted at: ingrid.schardinger@researchstudio.at

Florian Botzenhart has been a PhD student at the Max Planck Institute for Plasmaphysics in Garching, Germany since 2008. He undertook his Master's studies of Physics at the University of Augsburg (2002-2008), obtaining a Master's degree in 2008. His thesis title was "Optimal utilization of solar energy under thermodynamic and economic perspectives".

Markus Biberacher has been a Key Researcher at the Austrian Research Studios (RSA) since 2006 and was with the Centro de Investigaciones Energéticas, Medioambientales y Tecnológicas (CIEMAT) in Madrid (2005-2006). He was a PhD student at the Max Planck Institute for Plasmaphysics in Garching (2000-2004) and the topic of his thesis was modelling of energy systems in spatial context. He obtained a Diploma in Physics at the University of Augsburg in 2000.

Thomas Hamacher has been Professor and Acting Director at the chair of Energy Economy and Application Technology at the Technische Universitaet Muenchen (TUM) since 2010. Between 1996 and 2010 he was at the Max-Planck-Institute for Plasmaphysics in Garching (since 1999 head of the Energy and System Studies Division). He was a Post-doc at DESY and University of Texas, Austin: HERA-B-Experiment (1993-1996). He obtained a $\mathrm{PhD}$ in Physics at DESY (Deutsches Elektronen-Synchroton) in Hamburg (1993) and studied Physics in Bonn, Aachen and at Columbia University, New York (1983-1990).

Thomas Blaschke is a Professor at the University of Salzburg, Department of Geography and Geology, Co-Director Z_GIS Centre for Geoinformatics and Head of Research Studio iSPACE. He was a Fulbright Professor at California State University (2006); Professor for Geography and Geographic Information Systems at the University of Tübingen (2001-2003) and received a Marie Curie PostDoc fellowship at Manchester, UK (1998-1999). He obtained his PhD in Geography and Geoinformatics and his Diploma in Geography and Applied Geoinformatics from the University of Salzburg, in 1995 and 1992, respectively.

To purchase reprints of this article please e-mail: reprints@emeraldinsight.com Or visit our web site for further details: www.emeraldinsight.com/reprints 